\title{
Risk factors associated with white spot syndrome virus infection in a Vietnamese rice-shrimp farming system
}

\author{
F. Corsin ${ }^{1}$, J. F. Turnbull ${ }^{2}$, N. V. Hao ${ }^{3}$, C. V. Mohan ${ }^{4}$, T. T. Phi ${ }^{3}$, L. H. Phuoc ${ }^{3}$, \\ N. T. N. Tinh ${ }^{3}$, K. L. Morgan ${ }^{1, *}$ \\ ${ }^{1}$ Department of Veterinary Clinical Science and Animal Husbandry, The University of Liverpool, Leahurst, \\ Chester High Road, Neston CH64 7TE, United Kingdom \\ ${ }^{2}$ Institute of Aquaculture, University of Stirling, Stirling FK9 4LA, Scotland, UK \\ ${ }^{3}$ Research Institute for Aquaculture N.2, 116 Nguyen Dinh Chieu Street, Ho Chi Minh City, Vietnam \\ ${ }^{4}$ Fish Pathology Laboratory, Department of Aquaculture, College of Fisheries, UAS, Mangalore, India
}

\begin{abstract}
White spot disease (WSD) is a pandemic disease caused by a virus commonly known as white spot syndrome virus (WSSV). Several risk factors for WSD outbreaks have been suggested. However, there have been very few studies to identify risk factors for WSD outbreaks in culture systems. This paper presents and discusses the risk factors for WSSV infection identified during a longitudinal observational study conducted in a Vietnamese rice-shrimp farming system. A total of 158 variables were measured comprising location, features of the pond, management practices, pond bottom quality, shrimp health and other animals in the pond. At the end of the study period WSSV was detected in 15 of the 24 ponds followed through the production cycle $(62.5 \%)$. One hundred and thirtynine variables were used in univariate analyses. All the variables with a $p$-value $\leq 0.10$ were used in unconditional logistic regression in a forward stepwise model. An effect of location was identified in both univariate and multivariate analyses showing that ponds located in the eastern portion of the study site, closer to the sea, were more likely to test positive for WSSV by 1-step PCR at harvest. Ponds with shrimp of a smaller average size 1 mo after stocking tended to be positive for WSSV at the end of the production cycle. Average weight at 1 mo was also highlighted in multivariate analyses when considered as either a risk factor or an outcome. Other risk factors identified in univariate analyses were earlier date of stocking and use of commercial feed. A number of variables also appeared to be associated with a reduced risk of WSSV at harvest including the presence of dead post larvae in the batch sampled at stocking, presence of Hemigrapsus spp. crabs during the first month of production, feeding vitamin premix or legumes, presence of high numbers of shrimp with bacterial infection and the presence of larger mud crabs or gobies at harvest. No associations were detected with WSSV at harvest and stocking density, presence, or number or weight of wild shrimp in the pond. The multivariate model to identify outcomes associated with WSSV infection highlighted the presence of high mortality as the main variable explaining the data. The results obtained from this study are discussed in the context of WSD control and areas requiring further investigation are suggested.
\end{abstract}

KEY WORDS: White spot disease - Aquatic epidemiology - Risk factors - Penaeus monodon · Rice-shrimp farming system

Resale or republication not permitted without written consent of the publisher

\section{INTRODUCTION}

White spot disease (WSD) is a pandemic disease caused by a virus commonly known as white spot syndrome virus (WSSV). The acutely fatal effect of WSD and its devastating impact on the shrimp farming industry have been widely reported in the literature (Nakano et al. 1994, Wongteerasupaya et al. 1995, Anonymous 1997, Karunasagar et al. 1998, Park et al. 1998, Zhan et al. 1998).

\footnotetext{
${ }^{*}$ Corresponding author. E-mail: k.l.morgan@liv.ac.uk
} 
Several risk factors for WSD outbreaks have been suggested. These are stocking of infected post larvae (PL) (Limsuwan 1997, Flegel \& AldaySanz 1998, Mushiake et al. 1999, Withyachumnarnkul 1999); the addition of infected water to the pond (Nakano et al. 1994, Chou et al. 1998); the presence of WSSV carriers in the pond or inflow water (Lo et al. 1996, Kanchanaphum et al. 1998, Maeda et al. 1998); the occurrence of stress factors (Chou et al. 1995, Lo et al. 1996, Sudha et al. 1998); and the oral ingestion of infected shrimp or fresh feed (Chou et al. 1995, 1998). However, very few studies have investigated risk factors for WSD in working culture systems (Hettiarachchi et al. 1999, Withyachumnarnkul 1999).

Factors that increase the risk of disease in a population can be identified through the use of epidemiological techniques (Thrusfield 1986). Epidemiological studies have led to the identification of risk factors for aquatic diseases including furunculosis (Aeromonas salmonicida) and infectious salmon anaemia in Atlantic salmon Salmo salar (Jarp et al. 1995, Jarp \& Karlsen 1997), and vibriosis in rainbow trout Oncorhynchus mykiss (Thorburn 1987).

This paper presents and discusses the risk factors associated with WSSV infection in a Vietnamese riceshrimp farming system.

\section{MATERIALS AND METHODS}

A longitudinal observational study was conducted to identify the risk factors associated with WSD of Penaeus monodon in a rice-shrimp farming system in the Mekong delta of Vietnam (Fig. 1).

History, location, features of the pond, management practices, pond bottom quality, shrimp health, presence of other cultured and wild animals, and WSSV PCR products in wild and cultured crustaceans were measured in 24 ponds from January to June 1998. Twentythree ponds were followed for the whole production cycle, and 1 until it was stocked with additional juveniles from outside the study area. The study design and the methodology adopted for data collection have been described in detail elsewhere (Corsin et al. in press).

Variables. Dependent variable: The only dependent variable considered was the presence of WSSV as detected by 1-step PCR on pooled samples. Moribund shrimps were tested when available ( 4 ponds), while in
19 ponds 400 Penaeus monodon collected at harvest were used. In the pond where additional P. monodon from outside the study were stocked, PCR was carried out on 100 shrimp collected before extra shrimp were added.

The alkaline method (i.e., homogenisation of the sample in $0.05 \mathrm{~N} \mathrm{NaOH}$ and $0.025 \%$ SDS and boiling for $10 \mathrm{~min}$ ) was used for DNA extraction (Chanratchakool pers. comm.) and the samples were analysed by 1-step PCR according to Kim et al. (1998).

Independent variables. Location and features of the pond: Eleven variables related to the location and features of the pond were measured. The ponds were situated on a peninsula and their locations were categorised by dividing the study site into 2 equivalent regions depending on their position with respect to the main road, which ran approximately north-south. Each of these portions was further halved, thus obtaining 4 approximately equal areas. Pond, ditch and plateau area, and variables describing the presence of nipa palms Nipa fruticans and dikes inside the pond were also used in the analysis.

Management practices: Sixty-two variables relating to management practices throughout the production cycle were collected. Data on the source of the Penaeus monodon PL, the method of transportation to the pond and the practices adopted by the farmer at stocking were collected by interviewing the PL supplier and by direct observation.

During the production cycle, the farmers were interviewed twice weekly to collect data on the daily management activities. Data on the frequency and amount of feed, if any, lime or fertiliser applied, and the frequency and amount of water exchange were collected. Total amounts of nutrients applied were calculated from manufacturer analyses for commercial feeds and fertilisers, and feedstuff composition tables (Ministry of Agriculture and Food Industry Vietnam 1995) for feed prepared from raw materials. Two research assistants scored the management skills of the farmers independently at the end of the data collection period. These scores were based on the use of recognised management strategies for water exchange, feeding and application of substances (e.g., lime, fertilisers, treatments, etc.). In the Vietnamese system of shrimp production, ponds with cycles shorter than 3 mo are considered failures. A cut-off period of $75 \mathrm{~d}$ was therefore used to define an early harvest.

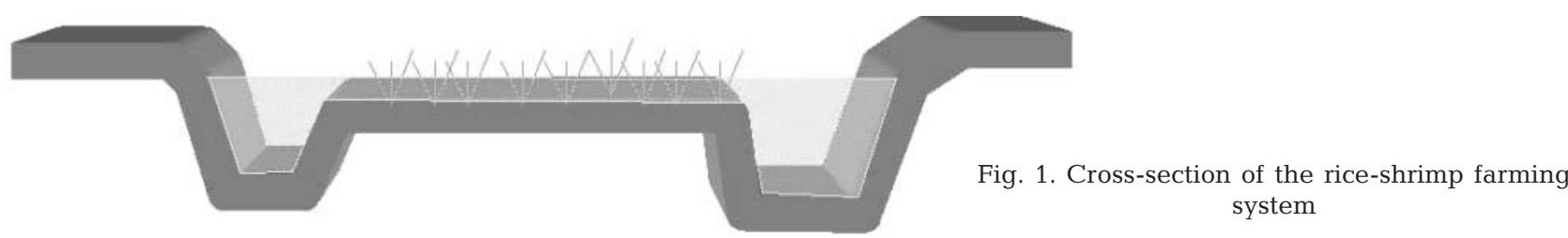


Pond bottom quality: Pond bottom quality was assessed monthly by measuring $\mathrm{pH}$, colour and smell. Data were analysed up to the point when the first of the 24 ponds was harvested.

Shrimp health: Data on shrimp health were collected at stocking, during the production cycle and at harvest producing 43 variables. At stocking, a sample of $500 \mathrm{PL}$ was collected to assess shrimp health and size. The sample was scored according to the activity and homogeneity in size of the PL (batch score) and by examining individual PL for chromatophore distribution, proportion of abdominal muscle in the shell, gut fill, presence of deformities, fouling organisms and histopathological changes in the hepatopancreas (Chanratchakool et al. 1998). To detect the presence of WSSV, 400 PL in batches of 50 were tested by PCR.

During the production cycle, Penaeus monodon were sampled by cast net at monthly intervals. The total number collected, external clinical signs, and weight and length of individual shrimp were recorded. Because of early harvests only the first sample taken 1 mo after stocking was collected from all 24 ponds; therefore, only these data were included in the analysis.

The number of dead Penaeus monodon detected by the farmer during the production cycle was recorded twice a week by interview. Presence and prevalence of clinical signs were also recorded from 100 shrimp collected at harvest or before additional shrimp were stocked in 1 pond. Presence of white spots under the carapace was also assessed in 400 shrimp at harvest. Data on the weight, grades and number of $P$. monodon within each grade were collected by farmer interview, from which data the total number of shrimp and shrimp survival were estimated.

Other animals in the pond: Data collected on the presence of other animals in the pond such as crabs, shrimp and fish were summarised into 32 variables. Crab samples were collected from the pond within a month after stocking and data on the presence and species composition were analysed. Gill samples were analysed by PCR to detect WSSV. Cultured giant freshwater prawn Macrobrachium rosenbergii were stocked in some of the ponds. Samples of these and any wild shrimp were collected by cast net 1 mo after stocking. The number, weight and WSSV PCR status of gills from these animals were recorded. The presence, weight, number and species of mud crab Scylla spp. were recorded at harvest from farmer interviews.

Data analysis. Univariate analysis: Of the 158 variables measured, 139 were used in univariate analyses. These were location and features of the pond (10 variables); management practices (52); pond bottom quality (10); shrimp health (40); and other animals in the pond (27). The selection of the variables for analysis was based on statistical power, and continuous vari- ables with fewer than 6 observations and categorical variables with fewer than 3 exposed or non-exposed ponds were not included.

Of the 139 selected variables, 104 were analysed by using 24 observations, each representing 1 pond. The remaining 35 variables were analysed using different numbers of observations as described below. Owing to restocking in some ponds the management practices $(7$ variables) and PL health data (11 variables) collected at stocking were analysed by considering each stocking event (i.e., 29 and 31 observations, respectively). To take account of differences in size when restocking occurred, analysis of data on Penaeus monodon weight and length data 1 mo after stocking ( 5 variables) was carried out only for ponds where different stocks were not mixed (i.e., 18 observations). The data related to the pond where shrimp were moved (6 variables) were also excluded from the analyses of harvested yield and survival variables. Owing to missing data the remaining 9 variables were analysed by using smaller data sets.

Continuous independent variables from WSSV positive and negative ponds were compared by ANOVA when the data were normally distributed and the variance was homogeneous (Bartlett's test at 5\% significance level), or by Kruskal-Wallis test for other data (Epi Info 6.04b, Dean et al. 1996). Median and quartiles were used as cut-off points to categorise variables. Categorical variables were analysed by testing $2 \times \mathrm{n}$ contingency tables with $\chi^{2}$ test or Fisher's exact test. Unadjusted odds ratios (ORs) were used for measuring the strength of associations. A p-value $\leq 0.05$ was considered significant in the univariate analysis.

Multivariate analysis: Variables with a p-value of $\leq 0.10$ in univariate analyses were used in unconditional logistic regression using a forward stepwise model (EGRET-Statistics and Epidemiology Research Corporation, Seattle, WA). The number of stocked PL $\mathrm{ha}^{-1}$ of ditch and the occurrence of emergency harvest were also included in the models to take into account the effect of stocking density and to correct for the confounding effect of the length of production cycle. Variables were fitted into the model individually and as interaction terms. All variables were initially used in the model as categorical variables, and replacement with their continuous counterparts was attempted at a later stage. Variables that prevented the model from reaching convergence were forced in and their effect assessed. The strength of associations was measured by adjusted ORs. Once the model had been developed, post-regression diagnostics aimed at assessing its robustness were carried out.

Two models to identify risk factors associated with the presence of WSSV were defined. The first model excluded variables related to weight and length 1 mo 
after stocking, since such variables could be considered to be the effect of WSSV. These variables were included in the second model.

Two models were also developed to assess the association between the possible effects of infection and the presence of WSSV (e.g., detection of mortalities, presence of white spots on the carapace, etc.) and the presence of WSSV: one excluding the weight and length variables from the cast-net sample after 1 mo and one including them.

To avoid a reduction in statistical power, variables with more than 1 missing value were excluded from the multivariate analysis leading to the analysis of 23 observations in each model.

\section{RESULTS}

\section{Presence of WSSV at the end of the study}

At the end of the study period WSSV PCR products were detected in 15 of 24 ponds (62.5\%; $95 \%$ CI 40.6 to $81.2 \%)$.

\section{Description of data and univariate analysis}

Location and features of the pond

The area to the east of the main road and nearest the sea had a higher proportion of WSSV infected ponds although this was not statistically significant $(\mathrm{OR}=$ 7.00; $\mathrm{p}=0.089$ ). In the south-eastern quadrant all the ponds (5 of 5) were positive for WSSV at harvest.

Although pond area ranged from 1869 to $7503 \mathrm{~m}^{2}$, infected and non-infected ponds had similar average sizes (3524 and $3489 \mathrm{~m}^{2}$, respectively). The ditch used for shrimp culture occupied approximately $1 / 3$ of the total pond area and ranged between 665 and $1813 \mathrm{~m}^{2}$ in size. The remainder was mostly left for rice culture but in 16 of $24(66.7 \%)$ ponds an area ranging from 32 to $584 \mathrm{~m}^{2}$ was occupied by dikes or small platforms above the pond water level built with the soil removed from the ditch. In 6 of 24 (25\%) of the ponds the topography of the pond was further complicated by the presence of nipa palms that covered an area of between 19 and $809 \mathrm{~m}^{2}$. None of the above features were significantly associated with the presence of WSSV at harvest.

\section{Management practices}

Stocking took place between 29 January and 14 February 1998. Seven of the 24 farmers (29.2\%) stocked more than once; this practice was not associated with the presence of WSSV. When the first stocking was considered alone, ponds that were stocked earlier had a higher risk of WSSV at harvest although this association was not statistically significant $(\mathrm{OR}=7.00$; $\mathrm{p}=$ 0.089). Since the individual hatchery that supplied the PL could not be identified, only the effect of hatchery location and PL supplier (middleman) on the presence of WSSV at harvest were analysed but no association was found. However, all ponds purchasing PL from Supplier 2 (2 of 2) and 3 (3 of 3) were WSSV positive at the end of the study period. PL were transported to the pond either by lorry or by plane (19 and 12 stocking events, respectively) at a density between 400 and $20000 \mathrm{PL} \mathrm{bag}^{-1}$ (3 to $5 \mathrm{l}$ in volume). No association was found between the method of transportation or the density in the bags and the outcome variable.

Once the PL arrived at the village, they were either released into the pond $(21$ of $31 ; 67.7 \%$ ) or held in concrete tanks (10 of $31 ; 32.3 \%$ ) where they spent a period of between $5 \mathrm{~h}$ and $3 \mathrm{~d}$ before being stocked. Once they reached the pond side, acclimatisation took place in 22 of 24 ponds $(91.7 \%)$. No association between the method of acclimatisation and WSSV presence at harvest was detected. After acclimatisation, the PL were released into a nursery area in 17 of $24(70.8 \%)$ of the ponds. This practice was not significantly associated with the outcome variable. Release of PL occurred between 06:00 and 23:30 h. There was no significant association between the time of release and the outcome, although all ponds that were stocked in the late afternoon (5 of 5) were infected with WSSV at harvest.

Farmers stocked between 2.7 and 14.0 PL m${ }^{-2}$ of pond with a stocking density of 10.1 and $34.5 \mathrm{PL} \mathrm{m}^{-2}$, respectively, of ditch. Stocking density was not associated with WSSV infection at harvest, neither when the whole pond nor when only the ditch area was used as denominator.

Feed prepared from raw materials was preferred to commercial feed by 23 of 24 (95.8\%) farmers. The most commonly used source of protein was wild Acetes spp. shrimp. This was used to a greater or lesser extent by all 24 farmers. Other protein sources were either cooked or raw fish, crabs, and other kinds of shrimp. There were no detectable associations between the protein source or the method of processing and WSSV at harvest.

Commercial chicken or pig feed, eggs and legumes were also added to the diet. Protective ${ }^{1}$ associations were found when feeding vitamin and mineral premix $(\mathrm{p}=0.041)$ and green beans $(\mathrm{OR}=11.2 ; \mathrm{p}=0.047)$.

\footnotetext{
${ }^{1}$ By 'protective' we mean an association with an apparent reduced likelihood of detecting WSSV at harvest. This does not imply a causative relationship
} 
Cereals such as corn ( 8 of $24 ; 33 \%$ ), rice bran (17 of 24 ; $71 \%$ ) and broken rice $(7$ of $24 ; 29 \%$ ), oilcake (6 of 24 ; $25 \%$ ), coconuts (5 of $24 ; 21 \%$ ) and soybean (4 of 24 ; $17 \%)$ were other ingredients incorporated into the feed, but no association of any of these with the outcome variable was detected.

Commercial shrimp feeds were given at least once during the production cycle in 18 of $24(75.0 \%)$ ponds. All 6 ponds where a particular brand of feed (feed 1) was used were WSSV positive at harvest $(p=0.052)$. Similarly, ponds that received more than $3.2 \mathrm{~kg}$ of any commercial shrimp feed were more likely $(\mathrm{OR}=7.00$; $\mathrm{p}=0.089$ ) to have WSSV PCR products at the end of the production cycle, although this association was not significant. A batch of Feed 1 was tested by 1-step PCR for WSSV but was negative.

To summarise the variability in kind of feed used, the estimated proximate composition of the different raw materials and commercial feeds was also analysed but no association with WSSV was detected. The estimated total amount of nitrogen and phosphorus from feeding was also analysed and again no association was found.

Several substances other than feed were added to the pond. Lime was used by 19 of 24 (79.2\%) farmers, while 13 of $24(54.2 \%)$ ponds were fertilised at least once through the addition of urea (6 of $24 ; 25.0 \%$ ), diammonium phosphate (5 of $24 ; 20.8 \%$ ), phosphate ( 2 of $24 ; 8.3 \%$ ), nitrogen phosphorus potassium fertiliser $(1$ of $24 ; 4.2 \%$ ) or rice bran ( 3 of $24 ; 12.5 \%$ ). Other products such as probiotics ( 6 of $24 ; 25.0 \%$ ) and zeolite ( 1 of $24 ; 4.2 \%$ ) were also added to the pond but only the application of higher amounts of fertiliser was associated with the presence of WSSV. This association only approached significance when the application of phosphorus by fertilisation was analysed $(\mathrm{OR}=7.00$; $\mathrm{p}=0.089$ ).

Water was exchanged in both infected and noninfected ponds (between 6 and 59 exchanges per production cycle) and no significant difference was detected between the 2 groups.

Since the farmers in this study were aware of the potentially devastating effects of WSD, 18 of $24(75 \%)$ harvested their ponds early because they thought their pond was suffering from a WSD outbreak. An association between early harvest and the presence of white spots under the carapace of harvested shrimp was detected $(p=0.003)$ but WSSV was detected in only 13 of the $18(72.2 \%)$ early harvest ponds. No significant association was detected between emergency harvest and the presence of WSSV at harvest $(\mathrm{OR}=5.20 ; \mathrm{p}=0.150)$.

To assess whether the overall management of the pond was associated with WSSV infection, at the end of the production cycle this variable was also analysed. Although farmers judged to have managed the farm poorly were at higher risk of contracting WSSV in their ponds, this association was not significant $(\mathrm{OR}=5.00$; $\mathrm{p}=0.428)$.

\section{Pond bottom quality}

Pond bottom variables were not significantly associated with the outcome. However, the presence of acidsmelling soil (i.e., the smell typical of mangrove soil) at first sampling was higher among the WSSV positive ponds (OR $=5.00 ; \mathrm{p}=0.099)$. Soil $\mathrm{pH}$ was also assessed against the outcome variable but, although an increase between first and second sampling was detected in all ponds (average 6.3 and 6.6, respectively), this was not associated with the presence of WSSV at harvest.

\section{Shrimp health}

Results of PL assessment at stocking indicated that the presence of dead PL in the batch sampled was protectively associated with the outcome $(p=0.060)$. With the exception of chromatophore expansion, all the PL scores indicated that larger numbers of good quality PL in the batch were associated with the presence of WSSV at harvest. When the PL were analysed for the presence of WSSV by 1-step PCR all the samples were negative.

After stocking, the shrimp population was again sampled at monthly intervals. Shrimp collected by cast-net after 1 mo of culture were highly variable in size among ponds with an average length from 49.7 to $80.3 \mathrm{~mm}$ and average weight between 0.92 and $4.47 \mathrm{~g}$. A significant association between small shrimp and WSSV was detected. Ponds with smaller and lighter shrimp were more likely to be WSSV positive at harvest $(p=0.068$ and 0.023 , respectively). Ponds with lower coefficients of variation of length and weight were also significantly more likely to be WSSV positive at harvest ( $p=0.035$ and 0.022 , respectively). None of the clinical signs recorded 1 mo after stocking were significantly associated with the presence of WSSV at harvest. However, all yellow-orange or blue shrimp in the first cast-net sample were collected from ponds that eventually tested WSSV positive at harvest ( 3 of $24 ; 12.5 \%$, and 1 of $24 ; 4.2 \%$, of the ponds, respectively). Similarly, shrimp with very poor activity, although detected in only 2 of 24 (8.3\%) ponds, were WSSV positive at harvest for both farms.

Dead shrimp were detected during the production cycle by farmers in 19 of 24 (79.2\%) ponds. There was no significant association between the detection of dead shrimp and WSSV infection. However, a strong association was found between the number of dead 
shrimp detected (more than 50 dead shrimp) and the outcome variable $(\mathrm{OR}=22.0 ; \mathrm{p}=0.009)$. Detection of dead shrimp in 18 of 19 (94.7\%) ponds also led to early harvest. Harvested shrimp showed several clinical signs such as white spots under the carapace, abnormal coloration, soft shell, damaged appendages and swelling of uropods or antennal scales associated with bacterial infection. Of these, the presence of white spots $(\mathrm{OR}=9.63 ; \mathrm{p}=0.033)$ and damaged appendages $(p=0.052)$ were associated with the presence of WSSV, while signs of bacterial infection in the antennal scales showed a protective association with the outcome $(\mathrm{OR}=8.00 ; \mathrm{p}=0.036)$. A pink body and the presence of shrimp with soft shell were more common in ponds infected with WSSV (for both OR $=5.25 ; \mathrm{p}=0.105$ ). On the other hand, WSSV negative ponds had a higher prevalence of bacterial infection in uropods $(\mathrm{OR}=5.25$; $p=0.105)$. No other clinical signs were associated with the outcome variable. When white spots at harvest were used as a test for the presence of virus the sensitivity was $77.3 \%$ and specificity $77.8 \%$.

The length of the production cycle ranged from 56 to $120 \mathrm{~d}$ and there was a great deal of variability among ponds in the total amount of shrimp harvested ha-1 of either the area of the whole pond (5.0 to $925.6 \mathrm{~kg} \mathrm{ha}^{-1}$ ) or the ditch (14.9 to $2811.2 \mathrm{~kg} \mathrm{ha}^{-1}$ ). Although there was no association between length of production cycle and presence of WSSV ( $p=0.685$ ), there was a relation approaching significance between low yield and WSSV ( $p=0.058)$. Shrimp harvested from WSSV positive ponds were significantly smaller and ponds with shrimp averaging $15 \mathrm{~g}$ or lower were more likely to be WSSV positive at harvest $(\mathrm{OR}=19.25$; $\mathrm{p}=0.009)$.

The total weight at harvest and the number of shrimp $\mathrm{kg}^{-1}$ allowed some estimations of survival to be made. Survival was between 1.2 and $71.5 \%$ and a strong association with the outcome variable was found when the first quartile was taken as the cut-off point; that is, 6 of 6 ponds with survival lower than $10 \%$ were WSSV positive $(\mathrm{p}=0.058)$.

\section{Other animals}

Several species of crustaceans and fish were detected in the ponds during the production cycle. Five species of crabs (Sesarma intermedia, Macrophthalmus japonicus, Thalassina anomala, Uca tetragonon and Hemigrapsus sanguineus) were collected during the first month after stocking. The presence of H. sanguineus was protectively associated with the presence of WSSV at the end of the study (OR $=11.20 ; \mathrm{p}=0.047$ ). Moreover, the total number of crabs caught was also associated with the outcome variable, indicating that ponds where fewer than 20 crabs were collected were more likely to test WSSV positive (OR $=5.5 ; \mathrm{p}=0.092)$. Information on mud crabs Scylla spp. was collected only at harvest due to the difficulties in catching them during the production cycle. Twenty-three (95.8\%) farmers found mud crabs in the pond. Their average weight ranged from 180 to $800 \mathrm{~g}$ and, although not significant, an association between presence of crabs smaller than $330 \mathrm{~g}$ and WSSV infection was detected $(\mathrm{OR}=7.50 ; \mathrm{p}=0.066)$.

In 6 of $24(25.0 \%)$ ponds, farmers also grew giant freshwater prawns with Penaeus monodon. However, there was no association between WSSV infection and the presence or size of these prawns at any stage of the production cycle. In 18 of $24(75.0 \%)$ ponds wild shrimps such as $P$. indicus, Metapenaeus lysianassa and $M$. ensis were detected during the first cast-net sampling, but no association with the outcome variable was detected. Similarly, no relation was detected between wild shrimp and WSSV infection at harvest when either the total number or weight of each species of shrimp was considered.

The presence of WSSV in crabs and wild shrimp collected during the first month of culture was examined by 1 -step PCR. All the samples tested negative.

At harvest, data on presence, amount and size of fish were also collected. Several species such as goby Glossogobius giurus, gudgeon Bostrichthys spp. or Eleotris spp., Asian seabass Lates calcarifer, tilapia Oreochromis spp., snakehead Ophicephalus spp. and catfish eel Plostosas spp. or Paraplotosus spp. were found to cohabit the ponds. The only fish population variable that was significantly associated with the presence of WSSV at harvest was the size of gobies. Ponds with larger gobies were significantly protected from WSSV infection $(p=0.001)$. A similar but non-significant protective association was also detected when the size of seabass was analysed $(\mathrm{p}=0.164)$.

\section{Multivariate analysis}

A causal web was drawn to facilitate the identification of interactions between variables. This is shown in Fig. 2.

\section{Risk factors for WSSV at harvest}

In the first model all variables with $p \leq 0.10$, excluding the weight and length of shrimp 1 mo after stocking, were used. When adjusted for confounding, the only variable that remained in the model was 'location'. Ponds located east of the road were at greater risk of being WSSV positive at harvest $(\mathrm{OR}=8.75)$ than those to the west (Table 1). 


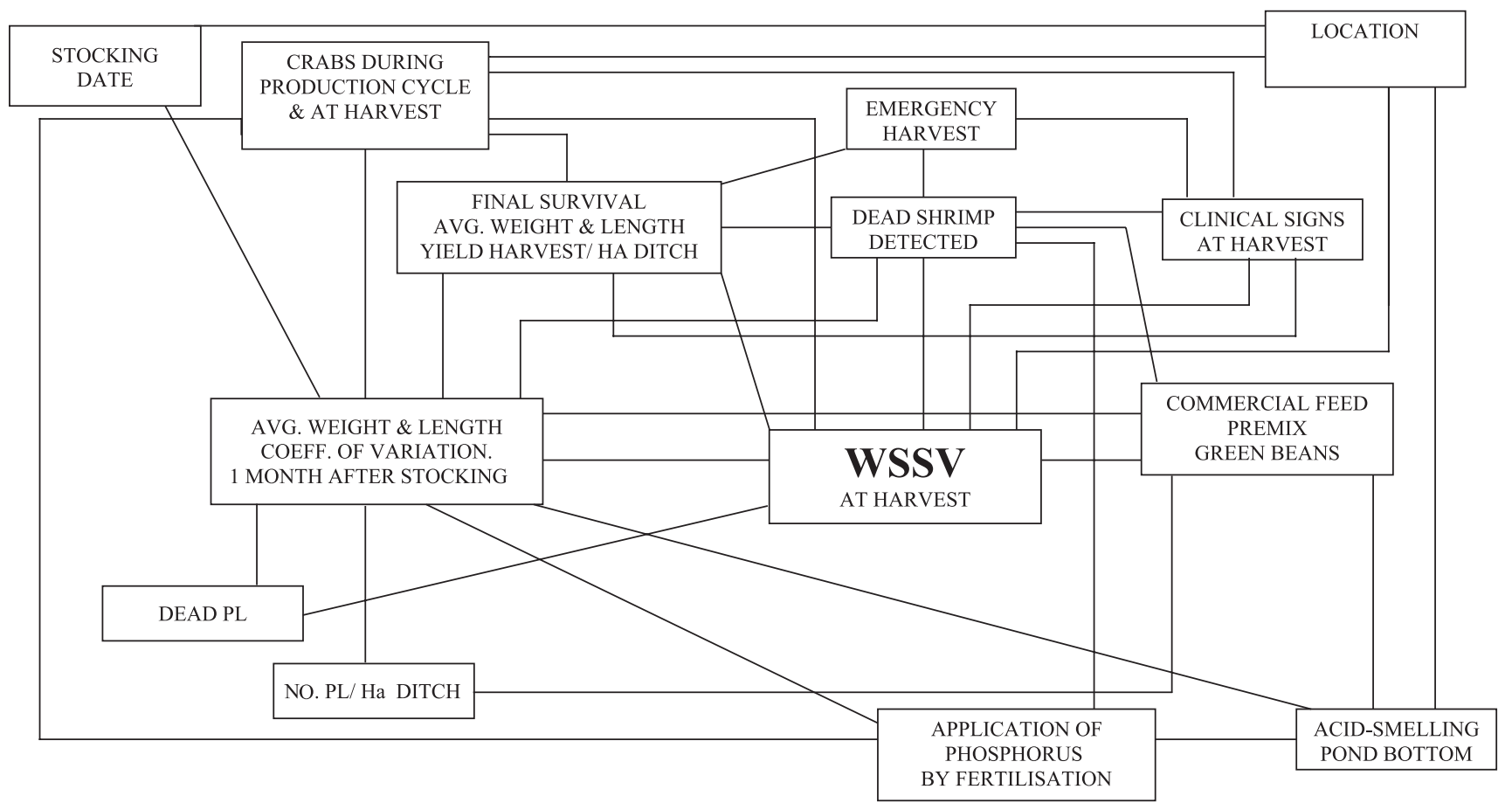

Fig. 2. Causal web used for identifying interactions between variables. PL: post larvae; WSSV: white spot syndrome virus

Owing to cells with zero values in both cases and controls, 'feeding of premix' could not be included in a model where it was the only variable used. 'Feeding green beans', 'feeding commercial Feed 1', 'number of crabs collected during the first month of culture' and 'presence of Hemigrapsus sanguineus' prevented the model reaching convergence. These were all offered to the model as interaction terms apart from the latter, which prevented convergence also when forcing it into the model was attempted.

The second model developed also included the average weight and length of shrimp 1 mo after stocking. Owing to failure in achieving convergence 3 variables could not be included: 'location', 'feeding green beans' and 'feeding of premix'. Two terms were identified as having a significant protective association: 'average

Table 1. Results of multivariate analyses. SE: standard error; OR: adjusted odds ratio; CI: confidence interval

\begin{tabular}{|c|c|c|c|c|c|c|}
\hline Model & Variable & Coefficient & $\mathrm{SE}$ & p-value & OR & $95 \% \mathrm{CI}$ \\
\hline $\begin{array}{l}\text { Model 1: } \\
\text { Deviance on } 21 \mathrm{df}=25.234 \\
\text { Likelihood ratio statistic } \\
\text { on } 1 \mathrm{df}=5.555, \mathrm{p}=0.018\end{array}$ & Location & 2.169 & 1.00 & 0.029 & 8.75 & $1.241-61.69$ \\
\hline $\begin{array}{l}\text { Model 2: } \\
\text { Deviance on } 21 \mathrm{df}=19.45\end{array}$ & Average weight at $1 \mathrm{mo}$ & -2.837 & 1.24 & 0.022 & 0.059 & $0.005-0.666$ \\
\hline $\begin{array}{l}\text { Likelihood ratio statistic } \\
\text { on } 2 \mathrm{df}=12.3, \mathrm{p}=0.002\end{array}$ & $\begin{array}{l}\text { No. shrimp with bacteria in } \\
\text { antennal scales at harvest }\end{array}$ & -2.315 & 1.25 & 0.063 & 0.099 & $0.008-1.138$ \\
\hline $\begin{array}{l}\text { Model 3: } \\
\text { Deviance on } 21 \mathrm{df}=21.305 \\
\text { Likelihood ratio statistic } \\
\text { on } 1 \mathrm{df}=8.416, \mathrm{p}=0.004\end{array}$ & $\begin{array}{l}\text { Total no. of dead } \\
\text { shrimp detected }\end{array}$ & 2.958 & 1.22 & 0.015 & 19.25 & $1.768-209.6$ \\
\hline $\begin{array}{l}\text { Model 4: } \\
\text { Deviance on } 21 \mathrm{df}=16.910 \\
\text { Likelihood ratio statistic } \\
\text { on } 2 \mathrm{df}=14.845, \mathrm{p}<0.001\end{array}$ & $\begin{array}{l}\text { Total no. of dead } \\
\text { shrimp detected } \\
\text { Average weight at } 1 \mathrm{mo}\end{array}$ & $\begin{array}{r}3.002 \\
-2.534\end{array}$ & $\begin{array}{l}1.42 \\
1.31\end{array}$ & $\begin{array}{l}0.034 \\
0.053\end{array}$ & $\begin{array}{l}20.13 \\
0.079\end{array}$ & $\begin{array}{l}1.255-322.9 \\
0.006-1.029\end{array}$ \\
\hline
\end{tabular}




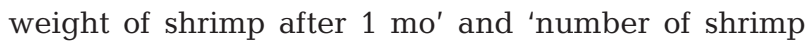
with bacterial infection in antennal scales at harvest' with ORs of 0.059 and 0.099 , respectively (Table 1).

\section{Effects of WSSV on production}

Two models aimed at identifying the major effects on production associated with WSSV infection were developed. In the first, excluding the average size and length 1 mo after stocking, all variables and interaction terms were evaluated. However, only the variable indicating the total number of dead shrimp entered the model to a significant level with an OR of 19.25 (Table 1). When a second model, including the average size of shrimp during the production cycle, was developed, the only variable that could not be included as an individual variable or as an interaction term was 'average weight 1 mo after stocking' and the result was identical to that found with the previous model. However, when 'average weight 1 mo after stocking' was forced into the model, a protective effect with an OR of 0.079 approaching significance was detected (Table 1).

\section{DISCUSSION}

This study dealt with the identification of risk factors associated with WSSV infection in a Vietnamese riceshrimp farming system. A longitudinal study design was used and, with the resources available, the maximum number of ponds that could be enrolled and followed over time was 24 . Such a sample size would allow a relatively powerful analysis of the time-dependent variables but is small for the identification of risk factors from a large set of variables. Statistical power was further reduced by the large variety of management practices adopted by the farmers. The constraints of a small number of replicates were also encountered during multivariate analysis where lack of convergence often occurred and post-regression diagnostics could not be carried out on any of the models developed. Despite these limitations, some significant associations were detected.

It is not clear what the source of WSSV was in the ponds that were positive at harvest. It appears, from the results presented here, that the virus must have entered with water or some unidentified carrier in the water such as planktonic organisms. However, it is also possible that the 1-step PCR was insufficiently sensitive to detect low levels of WSSV in other potential sources such as PL, wild crustacea or feed (Lo et al. 1996).

A strong association between WSSV infection at harvest and the location of the pond was found. In fact, when adjusted for confounding, this variable seemed to best explain the variability within the data. The ponds to the east of the road were more likely to be WSSV positive at harvest. Since no detectable differences in infrastructure were observed between the ponds on either side of the road, the most plausible explanation for this association seems to be their proximity to the sea. Ponds could have been infected through water or zooplankton, which are reported to be potential carriers of WSSV (Lo et al. 1996). A pond closer to the sea could also have been more exposed to other marine crustaceans such as crabs and shrimp. Infection of wild crustaceans with WSSV has been widely documented (Lo et al. 1996, Wang et al. 1997, Maeda et al. 1998, Mushiake et al. 1998), but in this study all samples of wild crustaceans were WSSV negative and there were no associations with 'WSSV at harvest' and 'wild shrimp in the pond'. In univariate analysis the presence of higher numbers of crabs in the ponds had a protective association with WSSV. Therefore, low numbers of crabs could be a predictor for WSSV infection as appeared to be the case for Hemigrapsus sanguineus. Although the association between the number of crabs and outcome could have been due to WSSV associated crab mortality in infected ponds and transmission of infection from crabs to shrimp (Kanchanaphum et al. 1998), a protective association between the size of mud crabs at harvest and the outcome was also detected. Similarly, the presence of larger gobies Glossogobius giurus was protectively associated with the presence of WSSV. The number and size of crabs and gobies may be an indication of a better environment for the survival and growth of aquatic organisms. However, it can also be hypothesised that larger mud crabs or gobies, which have carnivorous habits and feed near the pond edge (Khanna 1970), fed on moribund shrimp during outbreaks, thereby reducing the number of effective contacts between shrimp. These data are not completely consistent since no association was detected either with the presence or with the total number of mud crabs or gobies collected at harvest, and this prevents the drawing of any definite conclusion.

The association between WSSV infection and proximity to the sea may also explain the univariate association between early stocking and WSSV at harvest. At the onset of the dry season, ponds closer to the sea had salinity levels high enough for shrimp farming to occur earlier than in ponds located further inland. This explains why the effect of stocking date was not detected when adjusted for confounding. Date of stocking may also be associated with differences in WSSV status in the PL. This cannot be excluded despite the negative results by 1-step PCR. Seasonality of WSSV in broodstock and PL has been shown (Lo et al. 1997, Withyachumnarnkul 1999); however, since stocking in the 
study area occurred over a relatively short time (2 wk), a seasonal effect is unlikely.

None of the variables relating to source, transportation or treatment of PL was associated with the outcome. However, the lack of association may have been related to the variety of suppliers and treatments leading to a lack of statistical power. For example, although all 3 PL batches supplied by 1 supplier were WSSV positive at harvest, it is not possible to draw any conclusion due to the small sample size.

Of the PL health variables only the presence of dead shrimp was significantly associated with the outcome variable. Surprisingly, it showed a protective association. This finding was supported by the tendency for the majority of the other variables to indicate that 'good quality' PL were at higher risk of being WSSV positive at harvest. The reasons for this are unclear. It is possible that in batches with dead PL the weaker WSSV infected PL were eliminated before stocking. This hypothesis is supported by the success of formalin stressing PL before stocking as prevention for WSD (Limsuwan 1997). The method of PL assessment used in this study has been used to enable the farmers to select healthier PL batches (Chanratchakool et al. 1998). However, further studies are required to investigate the relation between the quality of the PL and the presence of WSSV at harvest.

Surprisingly, there was no association between stocking density and WSSV infection at harvest. Stocking density is generally believed to increase the likelihood of a disease outbreak by increasing the number of effective contacts between animals. This result may reflect the difficulties in measuring this variable. Considerable effort was expended in this study to calculate the actual stocking density through survey measurements of the ditch area and by monthly monitoring of the shrimp population by cast-net sampling. However, little information on the actual density of the shrimp in different parts of the pond was available. Shrimp distribution is not homogeneous. They tend to avoid areas of the pond bottom contaminated by organic waste and aggregate in cleaner areas. Therefore, in ponds with limited areas of clean pond bottom, the actual concentration of shrimp may be higher than estimated. This may also explain the univariate association between acid-smelling pond bottom and the presence of WSSV at harvest, although its disappearance in multivariate analysis suggests that this variable could have been confounded by location.

Smaller shrimp collected 1 mo after stocking showed a strong univariate association with WSSV infection at harvest. When included in multivariate analyses, average weight after 1 mo explained the data better than the location. Similarly, shrimp in ponds that eventually tested WSSV positive had significantly smaller coefficients of variation for both weight and length. It is not clear whether the average size and variability were outcomes or risk factors associated with WSSV infection. Shrimp might have been smaller either because the infection was inhibiting their growth or because of poor management practices that led to WSSV infection. In either case, the average weight at 1 mo may be a useful management tool for farmers as a predictor of infection at harvest.

The effect of management during the production cycle on the outcome variable was investigated extensively in this study. Some associations were found between feeding strategy and outcome. Feeding of commercial shrimp feed appeared to increase the risk of WSSV at harvest as all 6 ponds given Feed 1 were positive at harvest. The effect of the individual variable could not be assessed in multivariate analysis due to failure of the model to converge because of zero values. Some batches of the feed were tested using 1-step PCR but the result was negative.

Experimental infection of shrimp by mouth using infected tissues has been reported several times in the literature (Chou et al. 1998, Wang et al. 1999) but evidence to date indicates that WSSV cannot survive the processing temperatures of crustacean meals or of the pelleting process used to make shrimp feeds (Chang et al. 1998, Stevens et al. 1998). The association observed may be due to other factors connected to the use of commercial feeds such as feed quality, storage conditions and rancidity. The association observed in this study does, however, indicate that there is a need for further study to ascertain what relation there may be between the use of commercial feeds and the risk of WSSV presence.

While this study identified an association with commercial feed, no effect of using wild raw crustaceans as feed was detected. The presence of WSSV in wild crabs and shrimp including Acetes spp. has been widely documented (Lo et al. 1996, Maeda et al. 1998, Supamattaya et al. 1998). In this study, using wild raw crustaceans as feed did not appear to pose a significant risk. However, this does not preclude this route of infection under other circumstances.

Among other ingredients incorporated into the feed, interestingly, the addition of vitamin premix into homemade feed showed a protective association with WSSV at harvest, as did the addition of green beans. Some authors have suggested that vitamins may have a beneficial effect on the health of shrimp (Merchie et al. 1997, 1998). However, feeding shrimp dietary supplements could have been a proxy measure for better husbandry. Unfortunately no adjustment for confounding could be carried out since these variables did not enter any of the models developed. These findings deserve further investigation.

Overall management practices were assessed independently by the 2 research assistants. This was a sub- 
jective assessment but no association to WSSV was detected.

Of the other substances added to the pond, the only association with WSSV was a protective association of phosphorus applied through fertilisation. However, since farmers often increased the use of lime and fertilisers when dead shrimp were detected, these variables will be analysed in time-dependent models and results will be reported in a separate paper. When dead shrimp were detected, farmers also dramatically increased the frequency of water exchange. No association between total amount or frequency of water exchange and WSSV infection were detected in this study. However, the timing of exchange and location relative to infective ponds discharging water in the study will be investigated further.

Detection of dead shrimp led to other changes in management; primarily early harvest. Early harvest was conducted by 18 of 19 of the farmers who detected dead shrimp. Of these WSSV infection was detected in only 13. This indicates that on at least 5 occasions early harvest may not have been necessary. Such management decisions seem to be more common in other aquaculture systems than with terrestrial animals and may be due to the farmer's inability to adequately observe their stock. It also highlights the need for the use of a rapid pond-side diagnostic test for WSSV to assist the farmers in this decision.

The presence or absence of dead shrimp was not associated with WSSV at harvest. However, a strong association between high numbers of dead shrimp and the outcome variable was identified. This association was also detected in multivariate analyses where the number of dead shrimp detected best explained the variability within the data. Similarly, an association between low survival and WSSV infection was also observed in this study, reconfirming the widely reported mortalities associated with WSD outbreaks. Lower levels of mortality observed in some ponds might have been associated with other diseases such as vibriosis (Chanratchakool et al. 1998). Signs of bacterial infection at harvest were detected on both uropods and antennal scales. High numbers of shrimp showing signs of bacterial infection had a protective effect against WSSV infection at harvest and this effect remained when adjusted for confounding. This may reflect a more productive environment or a direct protective effect against the WSSV infection.

The presence of the characteristic white spots under the carapace and pink coloration was associated with WSSV infection. However, as a result of the low sensitivity and specificity it is debatable whether the presence of white spots is a useful guide to the presence of WSSV, especially in view of the existence of bacterial diseases producing the same clinical sign (Wang et al.
2000). The relation between white spots and clinical WSD was not evaluated in this study. Of the other clinical signs recorded at harvest, a univariate association between the presence of shrimp with appendage or shell damage and the outcome variable was also detected. This could have been a result of infection rather than a risk factor and could have been caused by cannibalism of moribund shrimp. The proportion of shrimp with soft shell was also higher in ponds infected with WSSV. This association could, however, have been confounded by the tendency for moulting to peak during full moon, which is also when water is exchanged more frequently, increasing the possibility of infection entering the pond. The relation among moulting, water exchange and WSD is obviously complex and requires further study.

In addition to the above clinical signs, shrimp harvested from WSSV positive ponds were also significantly smaller. This fact cannot be explained entirely by the occurrence of early harvest because of the lack of association between the length of the production cycle and the outcome variable. Smaller shrimp at harvest could have been a reflection of decreased growth rate but the possibility that during a WSD outbreak bigger shrimp die first cannot be excluded.

In spite of the limitations of analysing such a small data set, this study allowed the identification of several possible risk and protective factors. Many of these findings may be relevant only in this Vietnamese riceshrimp farming system and may differ over time. Therefore, the findings should be generalised with great care. The possible risk and protective factors identified here will have to be tested in intervention studies in order to develop effective health control strategies.

This work has raised a number of interesting questions, some of which are under further investigation. Others are outside the scope of this project and can only be addressed through further epidemiological investigations.

Acknowledgements. We are grateful to Richard Callinan, Pornlerd Chanratchakool, Michael Phillips, Ian MacRae and Rohana Subasinghe, who helped during the preliminary planning of the study. We would like to thank Nguyen Son Nam and Mai Van Chinh of the Agriculture-Rural Development Service of Long An Province, the officers of Can Duoc district and the Tan Chanh village committee for their collaboration. A special thanks goes to Nguyen Van Hen, who acted as liaison officer. We would like to thank also the Can Duoc extension workers for their co-operation and for sharing important information with the project team. We would like to thank all the members of RIA2 who contributed to the project for their help and co-operation. Thanks to Thao, Hoa and Hao for helping in assessing the PL quality. This study was supported by the British Government, Department for International Development through project R7051 of the Strategy for Research on Renewable Natural Resources Programme. 


\section{LITERATURE CITED}

Anonymous (1997) The blight of Asian farms. Fish Farm Int $24: 32$

Chang PS, Chen LJ, Wang YC (1998) The effect of ultraviolet irradiation, heat, $\mathrm{pH}$, ozone, salinity and chemical disinfectants on the infectivity of white spot syndrome baculovirus. Aquaculture 166:1-17

Chanratchakool P, Turnbull JF, Funge-Smith SJ, MacRae IH, Limsuwan C (1998) Health management in shrimp ponds, 3rd edn. Aquatic Animal Health Research Institute, Bangkok

Chou HY, Huang CY, Wang CH, Chiang HC, Lo CF (1995) Pathogenicity of a baculovirus infection causing white spot syndrome in cultured penaeid shrimp in Taiwan. Dis Aquat Org 23:165-173

Chou HY, Huang CY, Lo CF, Kou GH (1998) Studies on transmission of white spot syndrome associated baculovirus (WSBV) in Penaeus monodon and $P$. japonicus via waterborne contact and oral ingestion. Aquaculture 164: 263-276

Corsin F, Turnbull JF, Hao NV, Mohan CV, Phi TT, Phuoc LH, Tinh NTN, Morgan KL (in press) Problems and solutions with the design and execution of an epidemiological study of white spot disease in black tiger shrimp (Penaeus monodon). Prev Vet Med

Dean AG, Dean JA, Coulombier D, Burton AH, Brendel KA, Smith DC, Dicker RC, Sullivan KM, Fagan RF (1996) EpiInfo 6.04a. Division of Surveillance and Epidemiology, Epidemiology Program Office, Centers for Disease Control and Prevention, Atlanta

Flegel TW, AldaySanz V (1998) The crisis in Asian shrimp aquaculture: current status and future needs. J Appl Ichthyol 14:269-273

Hettiarachchi M, Pathiratne A, Somatilake RPH (1999) Effects of physico-chemical parameters of pond water and Vibrio infection on the occurrence of white spot disease in Penaeus monodon cultured in Sri Lanka. In: Fourth symposium on diseases in Asian aquaculture, Cebu, Philippines. Fish Health Section of the Fisheries Society, Manila, p OP27

Jarp J, Karlsen E (1997) Infectious salmon anaemia (ISA) risk factors in sea-cultured Atlantic salmon Salmo salar. Dis Aquat Org 28:79-86

Jarp J, Gjevre AG, Olsen AB, Bruheim T (1995) Risk-factors for furunculosis, infectious pancreatic necrosis and mortality in post-smolt of Atlantic salmon, Salmo salar L. J Fish Dis 18:67-78

Kanchanaphum P, Wongteerasupaya C, Sitidilokratana N, Boonsaeng V, Panyim S, Tassanakajon A, Withyachumnarnkul B, Flegel TW (1998) Experimental transmission of white spot syndrome virus (WSSV) from crabs to shrimp Penaeus monodon. Dis Aquat Org 34:1-7

Karunasagar I, Otta SK, Karunasagar I (1998) Disease problems affecting cultured penaeid shrimp in India. Fish Pathol 33:413-419

Khanna SS (1970) An introduction to fishes. Central Book Depot, Allahabad

Kim CK, Kim PK, Sohn SG, Sim DS, Park MA, Heo MS, Lee $\mathrm{TH}$, Lee JD, Jun HK, Jang KL (1998) Development of a polymerase chain reaction (PCR) procedure for the detection of baculovirus associated with white spot syndrome (WSBV) in penaeid shrimp. J Fish Dis 21:11-17

Limsuwan C (1997) Reducing the effects of white-spot baculovirus using PCR screening and stressors. AAHRI Newsl $6: 1-2$

Lo CF, Ho CH, Peng SE, Chen CH, Hsu HC, Chiu YL, Chang
CF, Liu KF, Su MS, Wang CH, Kou GH (1996) White spot syndrome baculovirus (WSBV) detected in cultured and captured shrimp, crabs and other arthropods. Dis Aquat Org 27:215-225

Lo CF, Ho CH, Chen $\mathrm{CH}$, Liu KF, Chiu YL, Yeh PY, Peng SE, Hsu HC, Liu HC, Chang CF, Su MS, Wang CH, Kou GH (1997) Detection and tissue tropism of white spot syndrome baculovirus (WSBV) in captured brooders of Penaeus monodon with a special emphasis on reproductive organs. Dis Aquat Org 30:53-72

Maeda M, Itami T, Furumoto A, Hennig O, Imamura T, Kondo M, Hirono I, Aoki T, Takahashi Y (1998) Detection of penaeid rod-shaped DNA virus (PRDV) in wild-caught shrimp and other crustaceans. Fish Pathol 33:373-380

Merchie G, Lavens P, Sorgeloos P (1997) Optimization of dietary vitamin $\mathrm{C}$ in fish and crustacean larvae: a review. Aquaculture 155:165-181

Merchie G, Kontara E, Lavens P, Robles R, Kurmaly K, Sorgeloos P (1998) Effect of vitamin C and astaxanthin on stress and disease resistance of postlarval tiger shrimp, Penaeus monodon (Fabricius). Aquacult Res 29:579-585

Ministry of Agriculture and Food Industry Vietnam (1995) Composition and nutritive values of Animal feeds in Vietnam. Agriculture Publishing House, Hanoi

Mushiake K, Arimoto M, Satoh J, Mori K (1998) Detection of PRDV from wild adult kuruma prawn. Fish Pathol 33: 503-509

Mushiake K, Shimizu K, Satoh J, Mori K, Arimoto M, Ohsumi S, Imaizumi K (1999) Control of penaeid acute viremia (PAV) in Penaeus japonicus: Selection of eggs based on the PCR detection of the causative virus (PRDV) from receptaculum seminis of spawned broodstock. Fish Pathol 34:203-207

Nakano H, Koube H, Umezawa S, Momoyama K, Hiraoka M, Inouye K, Oseko N (1994) Mass mortalities of cultured kuruma shrimp, Penaeus japonicus, in Japan in 1993: epizootiological survey and infection trials. Fish Pathol 29: $135-139$

Park JH, Lee YS, Lee S, Lee Y (1998) An infectious viral disease of penaeid shrimp newly found in Korea. Dis Aquat Org 34:71-75

Stevens WF, Cheypratub P, Haiqing S, Lertsutthiwong P, How NC, Chandrkrachang S (1998) Alternatives in shrimp biowaste processing. In: Flegel TW (ed) Advances in shrimp biotechnology. National Center for Genetic Engineering and Biotechnology, Bangkok, p 19-25

Sudha PM, Mohan CV, Shankar KM, Hegde A (1998) Relationship between white spot syndrome virus infection and clinical manifestation in Indian cultured penaeid shrimp. Aquaculture 167:95-101

Supamattaya K, Hoffmann RW, Boonyaratpalin S, Kanchanaphum P (1998) Experimental transmission of white spot syndrome virus (WSSV) from black tiger shrimp Penaeus monodon to the sand crab Portunus pelagicus, mud crab Scylla serrata and krill Acetes sp. Dis Aquat Org 32:79-86

Thorburn MA (1987) Factors influencing seasonal vibriosis mortality rates in Swedish pen-reared rainbow trout. Aquaculture 67:79-85

Thrusfield M (1986) Veterinary epidemiology, 2nd edn. Blackwell Science, London

Wang CS, Tsai YJ, Kou GH, Chen SN (1997) Detection of white spot disease virus infection in wild-caught greasy back shrimp, Metapenaeus ensis (de Haan) in Taiwan. Fish Pathol 32:35-41

Wang Q, White BL, Redman RM, Lightner DV (1999) Per os challenge of Litopenaeus vannamei postlarvae and Farfantepenaeus duorarum juveniles with six geographic 
isolates of white spot syndrome virus. Aquaculture 170: 179-194

Wang YG, Lee KL, Najiah M, Shariff M, Hassan MD (2000) A new bacterial white spot syndrome (BWSS) in cultured tiger shrimp Penaeus monodon and its comparison with white spot syndrome (WSS) caused by virus. Dis Aquat Org 41:9-18

Withyachumnarnkul B (1999) Results from black tiger shrimp Penaeus monodon culture ponds stocked with postlarvae PCR-positive or -negative for white-spot syndrome virus

Editorial responsibility: Timothy Flegel,

Bangkok, Thailand
(WSSV). Dis Aquat Org 39:21-27

Wongteerasupaya C, Vickers JE, Sriurairatana S, Nash GL, Akarajamorn A, Boonsaeng V, Panyim S, Tassanakajon A, Withyachumnarnkul B, Flegel TW (1995) A non-occluded, systemic baculovirus that occurs in cells of ectodermal and mesodermal origin and causes high mortality in the black tiger prawn Penaeus monodon. Dis Aquat Org 21:69-77

Zhan WB, Wang YH, Fryer JL, Yu KK, Fukuda H, Meng QX (1998) White spot syndrome virus infection of cultured shrimp in China. J Aquat Anim Health 10:405-410

Submitted: August 12, 2000; Accepted: May 7, 2001 Proofs received from author(s): October 10, 2001 